\title{
CONFLICT OF LAWS AND THE RESTATEMENT SECOND
}

\author{
WILLIS L. M. REESE*
}

\section{INTRODUCTION}

Conflict of laws is in a state of flux. This is particularly true of that most difficult area of the subject, which is frequently referred to as choice of law. Many fundamental rules in this area, that once were generally accepted, have been proved wrong by recent experience. ${ }^{I}$ Some of the remaining rules are being subjected to increasing criticism and doubt. More disconcerting is the fact that wide differences presently exist with respect to underlying objectives and values. The suggestion has even been made that all choice-of-law rules should be abandoned. ${ }^{2}$ This surely is a time for soul-searching and re-evaluation.

Conflict of laws was one of the first subjects to which the American Law Institute gave its attention. Work on the original Restatement was commenced in r923. At this time the teachings of Professor Joseph $\mathrm{H}$. Beale, the Reporter, were at their heyday. The vested rights theory, of which he was the principal exponent, was widely accepted, and it was generally believed that the entire field could be covered by a relatively small number of simple rules, as that the validity of a contract is governed by the law of the place of contracting and that rights and liabilities in tort are determined by the law of the place of injury. ${ }^{3}$ Little wonder as a consequence that the field was deemed ripe for restatement.

The situation had changed by the time the original Restatement was published in final form in 1934. The vested rights theory, the foundation on which the Restatement was constructed, was beginning to come under devastating attack from Professor Walter Wheeler Cook ${ }^{4}$ and others. ${ }^{5}$ This increasing turmoil and doubt had some effect upon the Restatement itself. Judge Goodrich once told the writer that the reason why the original comments are so terse and laconic is that the Advisers frequently disagreed with the reasons advanced by Professor Beale for his rules although they did not object to the rules themselves. As a result, proposed comments prepared by Professor Beale stating his reasons for the rules were fre-

- B.A. 1935, LL.B. 1938, Yale University. Charles Evans Hughes Professor of Law and Director, Parker School of Foreign and Comparative Law, Columbia University; Reporter, Restatement (SEcond), Confict of Laws.

${ }^{1}$ See generally Cavers, Change in Choice-of-Law Thinking and Its Bearing on the Klaxon Problem, American Law Institute, Study of the Division of Jurisdiction Between State and Federal Courts 154 (Tent. Draft No. I, I963).

' Currie, Notes on Methods and Objectives in the Conflict of Laws, I959 Duke L.J. 17I, I77.

- For a discussion of the vested rights theory, see Cheatham, American Theories of Confict of Laws: Their Role and Utility, 58 Harv. L. Rev. 36I (1945).

- Many of Professor Cook's articles are reprinted in Walter WheEler Cook, Logical and Legai BASES OF THE Conflict of LAWS (1942).

See, e.g., Lorenzen, Territoriality, Public Policy and the Confict of Laws, 33 YALE L.J. 736 (1924). 
quently rejected while the rules themselves were usually allowed to stand. With the exception of chapter eleven, which deals with the Administration of Estates, of which Judge Goodrich was the Reporter, the rules of the original Restatement in any event are simple, relatively few in number, and dogmatic. They are consistent with the vested rights theory and they give little indication of the fluidity and of the complexities and uncertainties of the subject.

It now seems evident, in the light of hindsight, that conflict of laws was not ripe for restatement in the r920's and I930's, at least in the usual way. The subject was then largely unexplored. This, rather than the Reporter's adherence to the vested rights theory, is believed to be the principal reason for what is now recognized to be the dogmatic and over-simplified character of the original Restatement. For it is in the nature of men to seek certainty and simplicity in the law. They will wish to regulate a field by a few simple rules if rules of this nature can be devised to handle adequately the problems involved. And if a few simple rules will handle adequately all, or at least the great majority, of problems that have arisen in a given field, men will be tempted to believe that the same rules can satisfactorily be applied to handle all other problems with which they may thereafter be faced. They will be loath to attempt to conjure up problems that may arise in the future and that could not adequately be handled by the suggested rules. In addition, Professor Beale had a great sense of order and of logic. He had an instinctive liking for simple, dogmatic rules and for theories that would lead to the adoption of such rules. Professor Beale was by no means alone in this regard. His views were shared by such learned and influential judges as Holmes ${ }^{6}$ and Cardozo, ${ }^{7}$ and, it seems safe to say, by the great majority of lawyers and law teachers of his time.

Following the appearance of the original Restatement in 1934, choice-of-law questions came before the courts with increasing frequency. It soon became apparent that many of the rules stated in this Restatement are wrong or at least so oversimplified as to be misleading. There was need for a complete revision, and work on such a revision was commenced in 1952. The Reporter of the Restatement Second and his Advisers have essentially two advantages over Professor Beale. They can profit from the criticisms that were directed at his work, and they can seek guidance from the large number of cases that have been decided, from the legislation that has been enacted, and from the books and articles that have been written since the appearance of the original Restatement. The Reporter and his Advisers, in short, have the opportunity of being more learned simply because there is now more to know.

On the other hand, revision of the Restatement at this time poses many difficulties. More, perhaps much more, is known about choice of law than when Professor Beale wrote. But this additional knowledge has not brought certainty and definiteness in its wake. Instead it has brought disagreement, a renewed search for fundamental

\footnotetext{
'See, e.g., Justice Holmes's opinion in Slater v. Mexican National R.R., 194 U.S. 120 (1904).
}

TSee, e.g., Benjamin N. Cardozo, The Paradoxes of Legal Science 67-68 (1928). 
values, and perhaps more uncertainty than ever before. What we do know now with fair certainty is that choice of law is too vast and complicated an area to be governed by a relatively small number of simple rules of general application. What is needed instead is a large number of relatively narrow rules that will be applicable only in precisely defined situations. ${ }^{8}$ But, with rare exceptions, experience to date is not sufficient to enable us to construct such rules or to identify all, or even most, of the situations to which such rules will be applicable. Choice of law, even now, is not ripe for restatement in the sense that it is rarely possible to state hard and fast rules with the reasonable assurance based on precedent and the resources of human reasoning and imagination that these rules will work well in all situations to which they literally can be applied.

In these circumstances, one obvious goal of the Restatement Second must be not to mislead. Care must be taken not to state rules that will prove wrong when applied to new problems, for if this were to be done with any frequency the Restatement would prove to be a hindrance, rather than an aid, in the further development of the subject. Hence, as a general proposition, it is probably better to err on the side of a rule that may be too fluid and uncertain in application than to take one's chances with a precise and hard-and-fast rule that may be proved wrong in the future. To be sure, a rule should not be stated so broadly that it would be consistent with almost any result that a court might reach. Such a rule would in effect be no rule at all. On the other hand, rules cannot bring certainty and predictability to a subject in which these values do not exist. Of necessity, many conflicts rules must be fluid in operation and leave much to be worked out by the courts. A Restatement, of course, must provide whatever guidance is possible. Hence the Restatement Second should state precise and definite rules in those few areas where this can be done. Elsewhere, broad, flexible rules must suffice. Such rules can be helpful, particularly if accompanied by a statement in the comments of the various policies that should guide the courts in applying them.

All rules of law, and choice-of-law rules are no exception, are the product of policies. A rule is constructed initially to further what the law-maker conceives to be the basic policies involved. And the ultimate success of a rule will depend upon how effective it is in furthering these policies. During the early stages of a rule's deveiopment, reference should constantly be made to the underlying policies to determine whether the rule is in need of amendment and whether it should be given a broad or narrow application. Only when the rule has become well established can it safely be applied without conscious reference to the policies involved. What has just been said is particularly applicable to choice-of-law rules. Few are well established and many are in their early stages of development. A court in applying these rules should have constant regard for the relevant policies. And the Restatement Second should state rules which in so far as possible will further them.

Some ten years ago Professor Cheatham and the writer published an article

${ }^{8}$ See Cavers, stipra note $\mathrm{I}$, at 165 . 
setting forth some of the policies which in their opinion should guide the courts in deciding choice-of-law questions and in formulating rules for choice of law. Time has not convinced the writer of the error of the views there set forth. It is proposed here to review briefly these policies and to consider the extent to which they are reflected in the rules set forth in the Restatement Second.

\section{The Polrcies}

The policies described in the article in the order of their mention are:

(I) The court must follow the dictates of its own legislature, provided these dictates are constitutional.

If there is any convincing indication, on the face of a statute or otherwise, of the desires of the enacting legislature with respect to the statute's range of application in space, it is the duty of the courts, subject to constitutional restrictions, to give the statute its intended application. Rarely, however, can this policy be applied in practice, because legislatures normally do not give thought to what should be the extraterritorial range of a statute but legislate only with the intrastate situation in mind.

(2) Choice-of-law rules should be designed to make the international and interstate systems work well. ${ }^{10}$

On occasion, this basic policy comes to the surface and we find the courts openly seeking to effectuate it. In the United States, this policy is most clearly evident in some opinions of the Supreme Court. Perhaps the opinions dealing with the statutory successor furnish the best example. ${ }^{11}$ An insolvent estate can be handled efficiently only by means of a unitary administration. Such an administration cannot be afforded a multistate corporation by a chancery receiver who can sue to collect assets and otherwise act in states not of his appointment only by the grace of those states. To remedy this situation, the Supreme Court seized upon the concept of the statutory successor and held in a series of decisions that such a successor must be permitted under full faith and credit to sue in sister states to collect stockholder assessments as well as other assets of the corporation. ${ }^{12}$ Another example of the policy openly at work is Hughes $v$. Fetter, ${ }^{13}$ where the Supreme Court was guided by "the strong unifying principle embodied in the full faith and credit clause looking toward maximum enforcement in each state of the obligations or rights

- Cheatham \& Reese, Choice of the Applicable Law, 52 CoLUM. L. REv. 959 (1952).

10 "It [the forum] must temper its freedom to declare local policy and its scope with a sense for harmonious interstate relations as well as for the justifiable expectations of the parties." 'Traynor, $1 s$ This Confict Really Necessary?, 37 TExas L. REv. 657, 675, (1959).

${ }^{11}$ See, e.g., Broderick v. Rosner, 294 U.S. 629 (1935); Clark v. Williard, 292 U.S. 112 (1934); Converse v. Hamilton, 224 U.S. 243 (I912); Cheatham, Note, The Statutory Successor, the Receiver and the Executor in Conflict of Laws, 44 Colum. L. Rev. 549 (1944).

13 See authorities cited in note II supra.

${ }^{18} 34$ I U.S. 609 (I95I). 
created or recognized by the statutes of sister states"14 in determining that Wisconsin was required by full faith and credit to entertain suit in its courts to recover for a wrongful death that occurred in Illinois.

This policy is also thought to support the rule that, with rare exceptions, the law of the state of incorporation governs the rights and liabilities of stockholders as well as matters relating to a corporation's internal structure and administration. ${ }^{15}$ Particularly in this country, where stockholders of a single corporation are often scattered among several states, it would be inconvenient indeed if stockholder rights and liabilities were not governed by a single law. Likewise in this country, where a corporation is likely to do business in many states, it would be almost intolerable if the law of each of these states were to be applied to determine such matters as the legality of a stock issue or of a dividend. There is need in such matters for the application of a single law, and this need is met by the rule that the law of the state of incorporation governs. ${ }^{16}$

Frequently, of course, it will be impossible to tell whether the needs of the international and interstate systems would best be served by the resolution of a given dispute one way or the other. In such instances, resort must be had to the other policies mentioned below.

(3) The court should apply its own local law unless there is good reason for not doing so.

A court should not assume the burden of ascertaining and applying the law of another state without good reason. So a court should apply its own law to matters that are not likely to affect the ultimate result of the case, such as rules of evidence and methods of service. As to still other matters, a court should also apply its own law unless it is required to do otherwise by one or more of the other policies mentioned here.

(4) The court should consider the purpose of its relevant local law rule in determining whether to apply its own law or the law of another state.

Every rule of law, whether embodied in a statute or in a common-law rule, was formulated in order to achieve one or more purposes. A court should have regard for these purposes in determining whether to apply its own rule or the law of another state to the matter at hand. If the purposes sought to be achieved by a local statute or common-law rule would be furthered by its application to an out-of-state occurrence, this is a weighty reason why such application should be made. It is only to be expected that a court will favor its own local policies over those of other states. For this reason primarily, a court will be inclined to give its own statutes and rules

${ }^{16} I d$. at $6 \mathrm{r} 2$.

${ }^{18}$ Restatement (Second), Conflict of LAws $\$ \$$ I66a, I82-186c (Tent. Draft No. 7, 1963); Reese \& Kaufman, The Law Governing Corporate Affairs: Choice of Law and the Scope of Full Faith and Credit, 58 Colum. L. Rev. III8 (1958); Coleman, Corporate Dividends and the Conflict of Laws, 63 Harv. L. Rev, 433 (I950).

${ }^{20} \mathrm{Sec}$ authorities cited in note 15 supra. 
a wider range of extraterritorial application than it will give to the statutes and rules of other states.

It must be remembered that, in contrast to the situation dealt with in connection with Policy No. I, we are here dealing with the usual case where the statute or common-law rule was formulated solely with the intrastate situation in mind and without thought to its possible extraterritorial application. ${ }^{17}$ Here the court acts as a free agent and has the pain of deciding whether the policies underlying a local statute or rule should be furthered at the expense of other choice-of-law policies and of the policies of the other interested states. The court must decide this question, since it was not decided by the legislature which enacted the statute or by the court which originally formulated the common-law rule.

There are two ways in which the court can approach the matter. Both will lead the court to the same ultimate result and, in essence, involve only verbalistic differences. Discussion of the two approaches will be clearer if made to revolve around the facts of a particular case. Bernkrant $v$. Fowler ${ }^{18}$ has been chosen for this purpose. In that case, the decedent had orally promised the plaintiffs that if they would pay in advance of the due date a substantial part of the indebtedness they owed him, he would provide by will that any part of the debt that remained unpaid at his death should be cancelled. Relying upon this promise, the plaintiffs prepaid a sufficient amount of the debt to meet the defendant's terms. About $\$ 6,000$ of the debt remained unpaid at the time of the decedent's death but his will made no provision for its cancellation. Accordingly, the plaintiffs brought suit in California against the decedent's executor to enforce the oral agreement. It appeared that the oral contract had been made in Nevada and that at all relevant times the plaintiffs were domiciled in that state. The decedent died domiciled in California. It was uncertain whether he had been domiciled in California or in Nevada at the time when the contract was made. The oral contract was found to be valid under Nevada law. On the other hand, a California statute provided that an agreement to make any provision by will is "invalid unless the same... is in writing...."10

Since the forum was a California court, it would be bound to follow, subject to constitutional restrictions, any directions of the California legislature as to the statute's range of application. The statute, however, contained no provision in this regard and, presumably, had been enacted only with the intrastate situation in mind. Almost surely, the enacting legislature had not given thought to the question whether the statute should be applied to invalidate an oral contract made in Nevada with Nevada domiciliaries. This being so, the first task of the court, since it was of California, would be to ascertain the purpose, or purposes, that were sought to be achieved by the statute. Almost certainly, the principal purpose of this statute was to protect the estates of California decedents againts false claims. Perhaps it was also

\footnotetext{
17 "In the main, local judges as well as legislators make law with the local scene only in mind...." Traynor, supra note 10, at $67 \mathrm{I}$.

${ }^{18} 55$ Cal.2d 588, 360 P.2d go6 (196r).

${ }^{10}$ Cal. Crv. COdE $\$$ I624(6).
} 
designed to protect the California courts against perjured testimony. In either event, the purpose, or purposes, underlying the statute would be furthered by having the statute applied to invalidate the Nevada contract. This, however, would not be the end of the matter. Since the legislature had not spoken on the point, the court, as stated above, would have to decide for itself what range of application the statute should have. The court would have to determine whether application of the statute in order to further its underlying purposes was worth the price that would be entailed.

One of the two ways in which the court could approach the question would be.to admit frankly that it has the power of decision and then to inquire whether the value of furthering the purposes sought to be achieved by the statute is outweighed in the particular case by other choice-of-law policies and by the policies of other states. This was the approach taken by Justice Traynor. He stated at the outset that California had an interest in having its statute applied but that

the Legislature, however, is ordinarily concerned with enacting laws to govern purely local transactions, and it has not spelled out the extent to which [this] statute... is to apply to a contract having substantial contacts with another state. Accordingly, we must determine its scope in the light of applicable principles of the law of conflict of laws. ${ }^{20}$

Justice Traynor continued by saying that it was possible that the decedent had been domiciled in Nevada at the time when the contract was made. If so,

the basic policy of upholding the expectations of the parties by enforcing contracts valid under the only law apparently applicable would preclude an interpretation of our statute of frauds that would make it apply to and thus invalidate the contract because Granrud [the decedent] moved to California and died here. ${ }^{21}$

The same result would follow even if the decedent had been domiciled at all relevant times in California. Nevada had a "substantial interest" in having its law applied, since the plaintiffs were domiciled in that state, the contract was made there and was performed there by the plaintiffs and "involved the refinancing of obligations arising from the sale of Nevada land and secured by interests therein."22 California also would have an obvious interest; and the problem facing the court, as Justice Traynor saw it, was to weigh "the policy to protect the reasonable expectations of the parties" against the policy represented by the California Statute of Frauds. ${ }^{23} \mathrm{He}$ held that the latter policy must give way because the plaintiffs at the time they made the contract would have no way of knowing whether the decedent would die domiciled in California or in some other state. "Unless they could rely on their own law, they would have to look to the laws of all jurisdictions to which Granrud [the decedent] might move regardless of where he was domiciled when the contract was made."24 In effect, therefore, Justice Traynor held that the

${ }^{20}{ }_{55} \mathrm{Cal} .2 \mathrm{~d}$ at 594,360 P.2d at 909.

21 Id. at $594-95,360$ P.2d at 909 .

22 Id. at 595,360 P.2d at 910 .

23 Id. at 596,360 P.2d at 9 ro.

${ }^{24}$ Ibid. 
policies underlying the California Statute of Frauds must bow before the choice-oflaw policies (a) of protecting the justified expectations of the parties; (b) of applying the law of the state of dominant interest; and (c) of upholding the fundamental policy underlying the local law field involved which, in the case of contracts, is to uphold contractual obligations assumed in good faith.

The other way for a court to approach the question is to pretend that its only task is one of statutory interpretation or, in other words, that it need only inquire whether the legislature did or did not intend to have the statute applied to the particular state of facts. If, as stated above, the legislature did express an intention on the subject, it is the duty of the courts to follow it, subject always to constitutional restrictions. But in the situation now under consideration, the legislature never thought about the matter at all. Hence a court following this approach must inquire what the legislature would have intended, or should have intended, had it thought about the problem. Since the court will naturally assume that the legislature was composed of reasonable men, it will almost inevitably suppose that the legislature would have been moved by the same considerations as would have moved the court. Hence if the court believes that the statute should not be applied because of such choice-of-law policies as protecting the justified expectations of the parties or attaining uniformity of result, it will assume that this must likewise have been the intention of the legislature. So, for example, we find Justice Traynor saying in Bernkrant v. Fowler that, because of the policy of upholding the expectations of the parties, "the California statute of frauds, in the absence of a plain legislative directive to the contrary, could not reasonably be interpreted as applying to the contract."25

Both approaches involve the same considerations and will lead to the same result. In both, it is the court that decides whether or not to apply the local statute to the foreign state of facts. The only difference is that a court following the first approach will frankly state that it is making the decision, while a court that adheres to the second approach will pretend to be effectuating the intentions of the legislature.

(5) Choice of law rules should seek to achieve certainty, predictability, and uniformity of result.

These are basic values throughout all areas of the law. They can, however, be purchased at too great a price. In a rapidly developing area, such as choice of law, it is often more important that there should be experimentation with new rules than that certainty and predictability of result should be assured through continued adherence to existing rules as to whose essential correctness there is legitimate doubt. Certainty and predictability are of particular importance in areas where the parties are likely to give advance thought to the legal consequences of their transactions. This is recognized, within limits at least, by existing rules of choice of law. So we find the courts virtually agreed that the validity of a will in so far as it concerns movables is governed by the law of the decedent's domicile at the time of

${ }^{25}$ Id. at 595,360 P.2d at 909 . 
death ${ }^{26}$ and by the law of the situs in so far as it concerns land. ${ }^{27}$ The courts likewise seek to apply a law that will sustain the validity of either a testamentary or an inter vivos trust. ${ }^{28}$ And in the area of contracts, where choice-of-law rules are uncertain, some measure of predictability and certainty is achieved by allowing the parties, within broad limits, to select the law to govern the validity and effect of their contract. $^{29}$

Uniformity of result is of pre-eminent importance when the transfer of an aggregate of movables, situated in two or more states, is involved. Here we find the courts, with considerable unanimity, adopting choice-of-law rules that permit such transfers to be governed by a single law. So, as stated above, the law of the decedent's domicile at the time of death is applied to determine the validity of his will in so far as it deals with movables; ${ }^{30}$ the same law is likewise applied to determine the distribution of movables upon intestacy. ${ }^{31}$ Also, with some exceptions, the law of the transferor's domicile is applied to determine the validity of an assignment of movables for the benefit of creditors. ${ }^{32}$ Uniformity of result is equally important in the case of marital property. For this reason, in part, the law of the spouses' domicile is applied to determine marital interests in movables, irrespective of where these may have been acquired..$^{33}$

Uniformity of result, or the application by all states of the same choice-of-law rule, is also desirable in order to avoid forum shopping. It is not to be expected, however, that differences in choice-of-law rules can ever be entirely eradicated. Likewise, freedom from forum shopping is not the most important value of all and should not be purchased at the sacrifice of all other relevant policies and at the risk of hindering the development of better rules of choice of law.

(6) The court should seek to protect the justified expectations of the parties.

This policy has already been seen at work in Justice Traynor's opinion in Bernkrant v. Fowler. ${ }^{34}$ It can only be operative in those situations where the parties give thought in advance to the legal consequences of their transactions. It is in part because of this policy that the parties are free, within broad limits, to choose the law to govern the validity of their contract, ${ }^{35}$ that the courts seek to apply a law that will sustain the validity of a trust of movables, ${ }^{36}$ and within narrower limits,

${ }^{20}$ Restatement (Sicond), Conflict of Laws $\$ 306$ (Tent. Draft No. 5, 1959).

${ }^{27}$ Id. $\S 249$.

${ }^{28}$ See, e.g., Shannon v. Irving Trust Co., 275 N.Y. 95, 9 N.E.2d 792 (1937); WaLter W. LaND, Trusts IN THE CONFLICT OF LAw'S II6 (1940); Cavers, Trusts Inter Vivos and the Conflict of Laws, 44 Harv. L. Rev. I6I (I930).

${ }^{20}$ See, e.g., Siegelman v. Cunard White Star, Ltd., 221 F.2d 189 (2d Cir. 1955); Restatement (SECond), Conflict of Laws $\S 332 a$ (Tent. Draft No. 6, rg60).

${ }^{80}$ RestateMsent (SeCond), Conflict of LAws $\$ 306$ ('Tent. Draft No. 5, 1959).

${ }^{31}$ Id. $\$ 303$.

${ }^{32} I d .5263$.

${ }^{33} I d . \$ 290$.

${ }^{34}$ See discussion at notes $18-25$ supra.

${ }^{35}$ See note 29 supra.

${ }^{30}$ See note 28 supra. 
the validity of a contract, ${ }^{37}$ and that the law of the last domicile is almost invariably applied to govern transfers of movables upon death. ${ }^{38}$ To some extent, this policy of protecting justified expectations is but another way of expressing the policy discussed immediately above. A person's expectations are likely to be disappointed if choice-of-law rules do not lead to uniformity, certainty, and predictability of result.

It must be remembered that the policy of protecting the parties' expectations is but one choice-of-law policy and will, on occasion, be outweighed by other policies. This may occur when the court is faced with the problem of deciding whether or not to apply the law of a state which is frankly designed to defeat expectations, as is true of the Statute of Frauds, ${ }^{39}$ of the Rule Against Perpetuities, ${ }^{40}$ and of rules designed to protect persons against exploitation, as in the case of usury laws ${ }^{41}$ and of small-loan legislation. ${ }^{42}$

(7) The court should seek to apply the law of the state of dominant interest

In general, it is fitting that the state whose interests are most deeply affected should have its law applied. Partly for this reason, the law of the situs is applied to determine the validity and effect of a conveyance of land, ${ }^{43}$ and the law of the spouses' common domicile is applied to determine the validity of their marriage ${ }^{44}$ and their respective interests in movables acquired during coverture.45 Which is the state of dominant interest may depend upon the issue involved. So if a husband injures his wife in a state other than that of their domicile, it may be that the state of conduct and injury has the greatest interest in determining such questions as whether the husband's conduct was negligent or otherwise tortious and whether the wife was contributorily negligent. On the other hand, the state of the spouses' domicile is the state of dominant interest when it comes to the question whether the husband should be held immune from tort liability to his wife. ${ }^{48}$ It should be for this state to determine whether marital harmony is preserved by making spouses immune from tort liability to each other and, if so, whether granting such immunity is worth the price.

Similarly, suppose that a driver and a guest passenger, who are both domiciled in state $X$, start upon a motor trip which is intended to take them from $X$ to a point in state $Y$ and then back to $X$, and that the guest sustains injury in an accident in state $Y$. Whether the driver was negligent, and the guest contributorily negligent,

\footnotetext{
${ }^{27}$ See, e.g., Pritchard v. Norton, ro6 U.S. 124 (1882); Ehrenzweig, Contracts in the Conflict of Laws, 59 Coldm. L. Rev. 973, Ir7I (1959); Restatement (SeCOND), Conflict of LAws $\$ 322 b$, comment 6 (Tent. Draft No. 6, rg60).

${ }^{38}$ RestateMeNT (SECOND), Conflict of LAWS $\$ 303,306$ (Tent. Draft No. 5, 1959).

${ }^{80}$ See Emery v. Burbank, I63 Mass. 326, 39 N.E. 1026 (1895); Rubin v. Irving Trust Co., 305 N.Y. 288, II3 N.E.2d 424 (1953); but cf. Bernkrant v. Fowler, 55 Cal.2d 588, 360 P.2d 906 (I96r).

${ }^{10}$ See authorities cited in note 28 supra.

11 Restatement (Second), Conflict of Laws \$334d (Tent. Draft No. 6 (1960).

${ }^{12}$ See, e.g., Kinney Loan and Finance Co. v. Sumner, I59 Neb. 57, 65 N.W.2d 240 (1954).

18 Restatement (Second), Conflict of Laws 215 (Tent. Draft No. 5, 1959).

"Restatement (Second), Conflict of Laws \$\$ 121, 122, 132 (Tent. Draft No. 4, 1957).

4E Restatement (Second), Conflict of Laws $\$ 290$ (Tent. Draft No. 5, 1959).

4s See, e.g., Haumschild v. Continental Casualty Co., 7 Wis.2d 130, 95 N.W.2d 8r4 (r959); Restatement (Second), Conflict of Laws $\$ 390$ g (Tent. Draft No. 8, r963).
} 
should, normally at least, be determined by the law of $Y$, which is in the state both of conduct and injury. On the other hand, $X$ law should be applied to determine the circumstances, if any, under which a guest passenger can recover damages from the driver for injuries caused by the latter's negligence. This is an issue with which $Y$ has little concern and with respect to which $X$ is clearly the state of dominant interest. ${ }^{4 \pi}$

Sometimes two or more states will have nearly equal interests in the decision of a case. If so, the policy under consideration can afford little assistance in the determination of the choice-of-law issue. It should also be stated that this is but one policy, which on occasion will be outweighed by others.

(8) Choice-of-law rules should be simple and easy to apply.

The importance of this policy should not be overemphasized. Pushed to its logical conclusion, it would lead to a rule that all cases should be decided according to the local law of the forum. The policy does, however, have some significance. It furnishes perhaps the principal support for the often stated rule that liability in tort is determined by the law of the state where defendant's conduct first resulted in injury.

(9) The court should seek to further the fundamental policy underlying the local law field involved.

Situations sometimes arise in which the policies of the interested states are largely the same but in which there nevertheless are minor differences between their relevant local law rules. In such instances, there is good reason for the court to apply the law of that state which will best achieve the fundamental policy underlying the local law field involved.

The usury cases provide an excellent example. ${ }^{48}$ Usury laws are designed to protect borrowers against excessive interest rates. Most states have laws of this sort, and these laws differ only slightly among themselves with respect to the maximum rate of interest that can legally be charged. In these circumstances, most courts will sustain a contract against the charge of usury if it is valid under the law of any state having a substantial contact with the transaction. This is done in order to give effect to the fundamental policy underlying the field of contracts, which is that promises should be performed. The rule seems a desirable one since the policies of the interested states are essentially the same, and hence the interests of one state cannot seriously be infringed by the application of another's law.

Another example of the policy at work can be found in the field of trusts, where the courts will go to considerable lengths to apply a law that will uphold the validity of a trust against the charge that it violates the Rule Against Perpetuities.99 The policy of all states on the subject of perpetuities is essentially the same and their laws differ only as to the length of time during which the power of alienation can

\footnotetext{
${ }^{17}$ Babcock v. Jackson, I2 N.Y.2d 473, I9I N.E.2d 279 (1963).

${ }^{48}$ Restatement (Second), Conflict of Laws $\$ 334$ d (Tent. Draft No. 6, 1960).

${ }^{10}$ See note 28 supra.
} 
be suspended, as lives in being, or lives in being plus twenty-one years. Here again the courts feel it more important to further the fundamental policy of trusts, which is to carry out the wishes of the settlor, than to apply the Rule Against Perpetuities of any particular state.

This policy is of less compelling force when there are significant differences in the relevant rules of the interested states. Finally, it can be of no assistance when several policies, none more fundamental than the rest, underlie the given legal field. An example is the law of torts, which, among other things, is designed to compensate the injured party, to deter tortious conduct, and to establish standards of rightful behavior. ${ }^{50}$

(10) The court should seek to attain justice in the individual case.

Usually, it will be difficult to tell where true justice lies. Also justice in the individual case, if it were given the most significant role, would be totally disruptive of all legal rules. Nevertheless, no judge will willingly reach a result which he deems to be unjust. And to some undefined extent, judges undoubtedly manipulate choice-of-law rules to permit them to apply the law of the state which to their mind will lead to the best result.

It is believed that this policy is most likely to carry the day in situations in which normal choice-of-law rules would lead to the application of the law of a state which adopts a minority view that is out of tune with the times. ${ }^{61}$ Here it is only to be expected that the court will search for a choice-of-law rule that would lead to the application of the law of some other state. Kilberg $v$. Northeast Airlines, Inc.52 is a case in point. There the court resorted to choice-of-law rules of dubious merit for the frankly avowed purpose of avoiding application of the provision limiting the amount of recovery contained in the wrongful death statute of Massachusetts, the state where the injury occurred and presumably the negligent conduct as well.

II

\section{Comment on the Policies}

With one exception, none of the policies described above is of such paramount importance as to outweigh all of the rest. The exception is Policy No. I, which requires a court to follow the dictates of its legislature provided that these dictates are constitutional. As previously stated, however, this policy can rarely be applied in practice, because legislatures normally legislate only with the intrastate situation in mind and do not give thought to the extent, if any, to which a statute should be applied to situations involving foreign facts. ${ }^{53}$

Decision of a choice-of-law question is easy when all, or most, of the policies point in a single direction. Decision becomes difficult when this is not the case.

\footnotetext{
${ }^{50}$ Eultott E. Cheatham, Herbert F. Goodrich, Ervin N. Griswold \& Willis L. M. Reese, Cases and Materials on Conflict of Laws 440-41 (4th ed. 1957).

${ }^{61}$ See, e.g., Siegmann v. Meyer, roo F.2d 367 (2d Cir. 1938).

${ }^{2} 9$ N.Y.2d 34,172 N.E.2d 526 (1961).

ss See text at note 17 supra.
} 
What is needed in this latter situation is the development of choice-of-law rules that will give effect to what are the most important policies, or policy, for the precise purpose at hand. Life would, of course, be easier if one policy always stood out from among the rest. But this simply is not true. The relative importance of the policies varies from situation to situation, and choice-of-law rules must recognize this fact.

Let us take in this connection Policy No. 4, which is that a court should consider the purpose sought to be achieved by its relevant local law rule in determining whether to apply this rule, or the law of another state, in the decision of a particular case. The extent to which application of the local law rule would result in the sacrifice of other choice-of-law policies, and the relative importance of these policies, will naturally vary from situation to situation. These variables will be considered by the courts in arriving at a choice-of-law decision.

For example, courts in this country, in the absence of an express legislative directive to the contrary, will apply the law of a decedent's domicile at the time of death to determine either the validity of his will with respect to movables or how these movables should be distributed in the event of an intestacy. ${ }^{54}$ The courts will apply this law to local movables even though their own rules are different and even though application of these latter rules would benefit local beneficiaries. The law of the last domicile is applied in this situation because of the obvious desirability of having the distribution of an estate of movables governed by a single law. The interests of all states would suffer if this were not the case. Likewise, and again in the absence of express legislative direction to the contrary, a court will usually not apply its own recording statutes to subordinate in favor of a local purchaser a security interest in a chattel that was brought into the state without the knowledge or consent of the security holder. ${ }^{5 \overline{5}}$ This rule is designed to encourage the free movement of goods from state to state. It is deemed to be in the interest of all states that security interest should be protected in this instance. On the other hand, in situations in which uniformity of result is not so important and where other significant choice-of-law policies do not stand in the way, there is greater justification for a court's applying its own local rule in order to further the purposes sought to be achieved by the rule. An example is Kilberg $v$. Northeast Airlines, Inc.56 where the New York Court of Appeals authorized application of the New York rule of damages in a suit to recover for the wrongful death of a New York domiciliary that occurred in Massachusetts. Uniformity of result is not of transcendent importance in tort and wrongful death cases for the reason, among others, that persons are unlikely to act on the assumption that in the event of an accident their rights and liabilities in tort will be governed by the law of a particular state.

st Restatement (Second), Conflict of Laws $\$ 306$ (Tent. Draft No. 5, I959); Griswold, Renvoi Revisited, 5I HARv. L. Rev. II65, II95 (I938).

${ }^{85}$ See, e.g., Metro-Plan, Inc. v. Kotcher-Turner, Inc., 296 Mich. 400, 296 N.W. 304 (I94I); Restatement (Second), Conflict of Laws $\$ \$ 268,275$ (Tent. Draft No. 5, 1959).

${ }^{80} 9$ N.Y.2d 34, I72 N.E.2d 526 (Ig6r). 
Partial justification, at least, for the Kilberg decision can be found in this fact. A somewhat similar situation exists in the area of contracts. Here choice-of-law rules, in the absence of an express provision on the subject in the contract, are uncertain in the extreme. Because of this uncertainty, uniformity of result is not easily attainable and the parties are unlikely to have had clear expectations with respect to the governing law. These considerations provide the court of an interested state with some justification for applying its own local law to a contract in order to further a local policy. On the other hand, as Bernkrant v. Fowler ${ }^{67}$ teaches us, the parties will naturally expect that the obligations of a contract will be fulfilled. This fact should make a court hesitate to apply its own local rule to strike down a contract which has its most significant relationship with another state.

It is also to be expected that the need of applying a local rule to foreign facts in order to further the purpose of the rule will vary from case to case. The intensity of this need is another factor that the court should consider in determining whether or not to apply its local rule.

To reiterate, no one policy, except the first, is of such paramount importance that it should always be given effect. Not only will the relative importance of these policies vary from one legal category to another, but each individual case is likely to present a different grouping of policies. Choice-of-law rules must eventually be developed that in so far as possible will take account of these variations. No single approach, no constant obeisance to a single policy will do. We must have narrower and more numerous choice-of-law rules. ${ }^{58}$ The task of constructing such rules will not be easy and, in many instances, must be based on greater experience than we presently have. Such difficulties are only to be expected in an area that presents so many complexities as does choice of law.

\section{III}

\section{The Restatement Second}

Two things should be stated by way of introduction to a discussion of the extent to which the policies described above are reflected in the rules of the Restatement Second. The first is that the Restatement states rules rather than policies. The policies are mentioned with some frequency in the Comments in order to explain and to justify the black-letter rules; they are not, however, referred to in the rules themselves.

The second is that the Restatement is written from the viewpoint of a neutral forum which has no interest of its own to protect and is seeking only to apply the most appropriate law. This approach is taken for the reason among others that some of the considerations that will induce a court to apply its own local law rather than that of another state are many and varied and are not susceptible to restatement. It can, of course, be said in criticism that cases rarely arise in truly neutral

${ }^{\text {st }} 55$ Cal.2d 588, 360 P.2d 906 (I96r).

is See Cavers, supra note $I$, at 165 . 
forums. This may well be true. Yet the fact remains that the approach adopted appears to be the only practicable one. Also even an interested forum will usually be guided by what it conceives to be correct rules of choice of law. Somewhere it will be made clear in the final version of the Restatement that the court of an interested state will depart from the rules stated in obedience to an express legislative mandate and on occasion, in the absence of such a mandate, in order to further an important local policy.

Since the Restatement is written from the viewpoint of a neutral forum, Policies No. I and No. 4 are often irrelevant. These policies are (a) that a court should follow the dictates of its own legislature and (b) that a court should give consideration to the purpose sought to be achieved by its relevant local law rule in determining whether to apply the rule in a case involving out-of-state facts. These policies have a bearing on the rules of the Restatement only when the forum is directed to apply the renvoi doctrine, that is, to refer both to the local and the conflicts law of the state of the governing law in order to decide the case in exactly the same way as a court of the latter state would have done. In these situations, the forum must determine whether a court of the state of the governing law would have been led by Policies No. I and No. 4, or by still other considerations, to apply its own local law to the decision of the case. Questions to which the Restatement directs application of the renvoi doctrine include (a) the validity of a marriage, governed by the whole (local and conflicts) law of the spouses' common domicile, ${ }^{59}$ (b) the transfer of land or of a chattel, governed by the whole law of the situs, ${ }^{60}$ (c) marital interests in movables, governed by the whole law of the spouses' domicile at the time of their acquisition, ${ }^{61}$ (d) the distribution upon death of land, governed by the whole law of the situs, ${ }^{62}$ and (e) the distribution upon death of movables governed by the whole law of the decedent's last domicile. ${ }^{63}$

The Restatement makes clear that a court of the state of the governing law would give effect to Policy No. I, that is to say, would follow the express commands of its legislature in determining whether to apply its own law or the law of another state in the decision of the case. So it is said, for example, that a court of the state of the governing law, if directed to do so by statute, would sustain the validity of a will with respect to formalities by application of the law of the state where the will was executed. ${ }^{64}$ Little is said about Policy No. 4 , on the other hand, because the considerations that will induce a court, in the absence of a legislative mandate, to apply its local rule in furtherance of a local policy are not susceptible to restatement. Mention is made, however, of situations in which a court will not apply its local law in deference to one or more choice-of-law policies. Examples already mentioned are that (a) courts will not, in the absence of an express legislative

\footnotetext{
${ }^{50}$ Restatement (Second), Conflict of LAws $\$$ I21, I22, I32 (Tent. Draft No. 4, I957).

${ }^{00}$ Restatement (Second), Conflict of Laws $\$ \$ 215,254^{2}$ (Tent. Draft No. 5, I959).

${ }^{\circ 1} I d . \$ 290$.

ox Id. $\$ \$ 245-254$.

${ }^{\text {co }}$ Id. $\$ \$ 303-309$.

- Id. $\$ 249$, comment $b$.
} 
directive to the contrary, apply their local recording acts to the prejudice of a security interest in the chattel which has been brought into the state without the knowledge or consent of the security holder, ${ }^{65}$ (b) the courts of the state of a chattel's situs, again in the absence of an express legislative directive to the contrary, will look to the law of the owner's last domicile to determine inheritance rights in the chattel, ${ }^{00}$ and (c) courts will go to considerable lengths to apply a law that will sustain the validity of a trust against the charge that it violates the Rule against Perpetuities. ${ }^{07}$ Still another example is to be found in the reluctance of the courts of the state of the spouses' common domicile to apply a local rule to invalidate a marriage good under the law of the state of celebration. ${ }^{68}$

It is said in the Restatement that the renvoi doctrine should not be applied to contracts $^{69}$ and torts. ${ }^{70}$ Hence Policies No. I and No. 4 have no application to the Restatement rules directed to these two areas, which in all probability present the most difficult choice-of-law problems.

Choice-of-law rules are to be found in those chapters of the Restatement which are directed to status, principally marriage and legitimation (chapter 5), agency and partnerships (chapter 5a), corporations (chapter 6), property (chapter 7), contracts (chapter 8), torts (chapter 9), and substance-procedure (chapter 12). Work on chapter twelve has not yet been commenced; hence this area will not here be discussed. By and large, fairly definite choice-of-law rules are stated with respect to status, corporations, and property. This is because the courts are generally agreed on what choice-of-law policies are entitled to the greatest weight in these areas.

According to the Restatement, the state of the spouses' common domicile has the ultimate voice in determining the validity of their marriage. ${ }^{71}$ This is because this state has the dominant interest in the marital status of its domiciliaries (Policy No. 7). For this reason, the renvoi doctrine is applicable and the courts of other states will seek to decide the case in exactly the same way as would have been done by the courts of the state of the common domicile. On the other hand, the courts of the common domicile will usually uphold the validity of a marriage that is good under the law of the state of celebration. This is done in order to protect the expectations of the parties (Policies No. 5 and No. 6), and because of the general policy in favor of upholding the validity of marriage (Policy No. 9). Questions of legitimation are said by the Restatement to be governed by the law of the domicile of the parent against whom the child claims legitimacy. ${ }^{72}$ This state will normally at least have as great an interest in the matter as any other (Policy No. 7). Likewise, application of its law may often be required by considerations of

\footnotetext{
${ }^{\circ \mathrm{C}} I d . \$ \$ 268,275$.

${ }^{60} I d$. $\$ \$ 303,306$.

${ }^{67}$ Id. $\$ 294$, comment $e$; $\$ 295$, comment $d$.

${ }^{68}$ Restatement (Second), Conflict of Laws \$ $\$ 21,132$ (Tent. Draft No. 4, 1957).

${ }^{60}$ Restatement (Second), Conflict of Laws $\$ 332$, comment $e$ (Tent. Draft No. 6, I960).

${ }^{70}$ Restatement (SECOND), Conflict of Laws $\$ 379$, comment $e$ (Tent. Draft No. 8, I963).

71 Restatement (Second), Conflict of Laws $\$ \$$ I21, 132 (Tent. Draft No. 4, 1957).

${ }^{72}$ Id. $\$ \S 137-140$.
} 
justice to the parent involved (compare Policy No. ro). The renvoi doctrine is also said to apply in this situation. If the courts of the state of the parent's domicile would determine the question of legitimation by reference to the law of another state, the forum will probably do likewise.

Questions involving the internal affairs of corporations are said, with one possible exception, to be governed by the law of the state of incorporation. ${ }^{73}$ Such questions include the rights and liabilities of stockholders, the liability of directors and officers to the corporation and its stockholders, stockholders' and directors' meetings, the election of directors, and the validity of stock issues and of dividend payments. Frequently, the state of incorporation will be the state of dominant interest. But the rule is also applicable in situations where the corporation's contacts with the incorporating state are relatively slight and where its principal place of business is elsewhere. Explanation for the rule can be found in the needs of the situation, namely that it is of the utmost importance that matters involving a corporation's internal affairs should be governed by a single law and the state of incorporation is not only easily ascertainable but is also the one that the parties would presumably expect to have applied. A further reason for the rule is that choice-of-law rules should here be definite and clear because this is an area where the parties and their lawyers will normally give deep consideration to possible consequences of proposed conduct before they embark upon it. Hence it would appear that choice-of-law rules are here the product of Policies No. 2 (needs of the interstate system), No. 5 (certainty, predictability and uniformity of result), No. 6 (expectations of the parties), and No. 8 (ease of application). These policies likewise dictate that questions of this sort should be decided in accordance with the local law of the state of incorporation.

Turning now to property, transfers of land are said to be governed by the law of the situs. ${ }^{74}$ This is the state of dominant interest (Policy No. 7), and the rule leads to certainty and uniformity of result (Policy No. 5) and is easy to apply (Policy No. 8). Usually, the courts of this state would apply their own local law in deciding the case. In the rare situations in which they would look to the law of another state, as where they are directed by statute to sustain the validity of a will as to formalities if it meets the requirements of some other state, the forum will do likewise.

Chattels present more difficult problems. Because chattels can be moved from state to state, no state is likely to have the same degree of interest in a chattel that it has in local land. ${ }^{75}$ Nevertheless, the Restatement provides that the law of the situs governs. The clearest situation is that in which, after a security interest, as a conditional sale or chattel mortgage, has been created in the chattel in one state, the chattel is removed to a second state and there is the subject of a second transaction, as a sale to a bona fide purchaser. Here the law of the second state is applied to

${ }^{73}$ Restatement (Second), Conflict of I.aws $\$$ i66a (Tent. Draft No. 7, r963).

7 Restatement (Second), Conflict of I aws $\$ 215$ (Tent. Draft No. 5, I959).

${ }^{70}$ Id. $\$ 254 \mathrm{a}$. 
determine the effect of the later transaction upon the prior security interest. ${ }^{70}$ If the chattel was brought into the state without the knowledge or consent of the security holder, the courts of the second state, in the absence of an express legislative directive to the contrary, will not, as stated above, apply their local recording act to subordinate the interests of the security holder to those of the bona fide purchaser. ${ }^{77}$ The forum, in any event, is directed by the Restatement to apply whichever law would have been applied by the courts of the second state in deciding the case. These rules rest in part upon the interest of the state of the situs (Policy No. 7). To a greater extent they stem from the policy of protecting the expectations of the parties (Policy No. 6), since one who deals with a chattel would naturally expect that the law of the state where the chattel is situated at the time would be applied to determine the interests that he acquires. On the other hand, he would also realize that the chattel might be moved to another state and that in this event the law of the other state might be applied to determine the nature of the interests acquired by one who there dealt with the chattel. Also, of course, the rule is easy to apply (Policy No. 7) and leads to certainty, uniformity, and predictability of result (Policy No. 5).

The problem becomes more difficult when the controversy with respect to the chattel is between parties to a single transaction, as when the issue is whether a given transaction resulted in the outright sale of the chattel or in a chattel mortgage or whether the security holder has sold the chattel in violation of the debtor's rights of redemption. ${ }^{78}$ Here the question is whether the governing law should be that of the chattel's situs at the time of the transaction or the law which governs the contractual relationship between the parties. This would be the law of the state which has the most significant relationship with the parties and the transaction. ${ }^{79}$ Much can be said in favor of the latter solution. It provides desirable flexibility and would appear to be in line with the policy that looks towards application of the law of the state of dominant interest (Policy No. 7). On the other hand, application of the law of the situs would find support in the policies of certainty, uniformity, and predictability of result (Policy No. 5) and ease of application (Policy No. 8). The Restatement presently provides that the law of the situs governs, but says that the courts of this state might apply the law that governs the parties' agreement in determining their interests in the chattel..$^{80}$ In this event, the forum is directed to do likewise. The authorities are uncertain in this area, ${ }^{81}$ and it may be the Restatement will be amended in its final form to make solely applicable the law that governs the parties' agreement.

The situation is different when the transfer of an aggregate of movables situated

${ }^{36} 1 d$. $\$ \$ 268-27 x, 274-278$.

${ }^{77}$ See text at note 65 supra.

${ }^{78}$ Restatement (SeCOND), Confeict of Laws $\$ 254$ a, comment $b$ (Tent. Draft No. 5, 1959).

70 Restatement (Second), Conflict of Lams $\$ 5$ 332-332b (Tent. Draft No. 6, 1960).

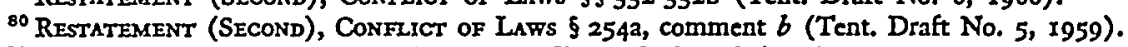

${ }^{81}$ See Cavers, The Conditional Seller's Remedies and the Choice-of-Law Process, 35 N.Y.U.L. Rev. 1126 (1960). 
in two or more states is involved. Here it is obviously desirable that the transfer should be governed by a single law. So, the Restatement provides that the validity and effect of a will of movables and the distribution of movables upon intestacy are governed by the law of the decedent's domicile at the time of death, ${ }^{82}$ marital interests in movables acquired during coverture are governed by the law of the spouses' domicile at the time of acquisition, ${ }^{83}$ and an assignment of chattels for the benefit of creditors is governed by the law of the transferor's domicile at the time. ${ }^{84}$ Likewise, the validity and administration of a trust of movables situated in two or more states are said to be governed by a single law. ${ }^{85}$ These rules are clearly in line with the policy of making the international and interstate systems work well (Policy No. 2) and of the policy in favor of uniformity of result (Policy No. 5).

Nothing will here be said about the Restatement rules on agency and partnerships. $^{80}$ These rules are based in large part upon choice-of-law rules relating to contracts and torts. These latter rules will now be discussed.

Contracts is an area in which the parties are likely to give advance thought to the legal consequences of their conduct. There is real need here for choice-of-law rules that will bring certainty, predictability, and uniformity of result (Policy No. 5) and that will protect the parties' expectations (Policy No. 6). These values are achieved in some degree by the Restatement rule that, subject to certain limitations, the parties may choose the law to govern the validity and effect of their contract. ${ }^{87}$ Where the parties have not made such a choice, the Restatement provides that the governing law is that of the state which has the most significant relationship with the contract. ${ }^{88}$ The effort is made in the case of particular contracts to state what contact, as the situs of land in contracts dealing with land, will be considered most important by the courts in determining the state of most significant relationship. ${ }^{89}$ The rule of most significant relationship is undoubtedly too vague to offer firm guidance in situations where the important contacts are divided more or less equally among two or more states. It is believed, however, that no more definite rule can be stated in view of the relatively unexplored state of the field and the existing confusion among the authorities. A more definite rule would almost surely be proved wrong in the course of time and might actually impede constructive progress.

There are many different kinds of contracts and a vastly greater multitude of issues relating to contracts. The laws of the various states also differ markedly as to the requirements that these contracts must fulfill in order to be valid and entitled to legal effect. Also the contacts which a contract may have with two or more states are likely to differ markedly from case to case. Experience has shown that

8s Restatexent (SecoND), Conflict of Laws $\$ \$ 303,306$ (Tent. Draft No. 5, 1959).

${ }^{88}$ Id. $\$ 290$.

84 Id. $\$ 263$.

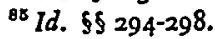

${ }^{80}$ Restatement (Second), Conflict of Laws $\$ 9$ I5ra-rjie (Tent. Draft No. 7, I963).

${ }^{87}$ Restatedent (Second), Conflict of Laws $\$ 332 a$ (Tent. Draft No. 6, I960).

${ }^{88}$ Id. $5332 \mathrm{~b}$.

"Id. $\$ \$ 364 \mathrm{e}-364 \mathrm{n}$. 
this large and complicated area cannot adequately be handled by a few single rules. What is needed instead is a large number of rules that are each directed to a relatively narrow situation. Experience to date is not sufficient to permit the formulation of many such rules at the present time. The task of doing so must be left to the future. These rules will have to be developed on a case-to-case basis in the light of all of the policies outlined above. It would, of course, be far easier if it were possible to say that consideration need be given to only one of these policies, as that a court should apply its own law when to do so would further a local interest or, in order to protect the expectations of the parties, should apply a law which will validate the contract. ${ }^{90}$ Such a view, however, would vastly oversimplify the problem and would probably prove to be as incorrect as the equally simple, and much criticized, rule of the original Restatement that the validity of a contract is governed by the law of the place of contracting.

A rule of validation, for example, would have much superficial attraction and could marshal considerable authority in its support. Undoubtedly, courts on many occasions have sought to uphold a contract by application of a favorable law.11 But it must be remembered that there are many kinds of contracts and that some of them may be deemed socially undesirable or at least less desirable than others. Likewise, all states have laws which, largely for the purpose of protecting the weak against the strong, limit the parties' freedom to contract by invalidating certain kinds of contractual provisions. Whether a court will seek to apply a validating law in a given case will depend upon the kind of contract or contractual provision involved and also upon the degree of interest which the state of the validating law has in the parties and the transaction.

A rule of validation would also be impossible to apply in the familiar situation where a party claims that he has been relieved of his contractual obligation through the operation of a particular provision in the contract, as that he shall not be held liable in the event of a particular occurrence, or that no suit shall be brought later than a specified time after the occurrence of a loss or injury. ${ }^{22}$ Here if the court validates the provision it must perforce hold the obligation ineffective. In order to uphold the obligation, the court must invalidate the provision. In either case, the court must both validate and invalidate. No principle of validation can furnish it with an effective guide.

There is no easy short cut. In each case, all of the policies must be considered and a choice-of-law rule developed that will give effect to what are the most important policies for the precise purpose at hand. It is felt as a result that the Restatement cannot usually do more in the case of contracts which contain no choice-of-law provision than to state the general principle of state of most significant relationship in the black letter rule and then to mention in the comments the more important considerations that should motivate the courts in arriving at a decision

${ }^{20}$ See Ehrenzweig, supra note 37 .

${ }^{91}$ See, e.g., Pritchard v. Norton, 106 U.S. 124 (1882).

${ }^{22}$ Auten v. Auten, 308 N.Y. 155, 124 N.E.zd. 99 (1954), provides another example. 
and in general to give whatever guidance is possible. At the very least, such black letter rules and comments will not mislead an unwary court or litigant into believing that the area is governed by well-settled rules.

Torts present different considerations. Rarely do parties contemplate the consequences of tortious conduct, and rarely if at all will they give thought to the question of what law would be applied to govern their conduct if it were to result in injury. In other words, uniformity, certainty, and predictability of result are not as important values in this area as they are in contracts. Until recently, the courts with rare unanimity applied the law of the place of injury to determine rights and liabilities in tort. ${ }^{93}$ Recently, however, several important courts have either expressed dissatisfaction with the rule or else have reached results that are inconsistent with it. ${ }^{94}$ This trend will probably continue and it is thought that the rule will become eroded, at least in part, in the course of time. As a result, the Restatement has adopted in this area also the rule of most significant relationship. ${ }^{95}$ The effort is also made, as in the case of contracts, to state with respect to particular torts what contact, as the principal location of the defendant's conduct in the case of alienation of affections, will be considered most important by the courts in determining the state of most significant relationship. ${ }^{96}$

This rule of most significant relationship, at the very least, will not stand in the way of progress. It should aid in inducing the courts to depart from the place of injury rule in situations where this is desirable. And it should make clear to the lawyer and litigant that it can no longer be expected that the place of injury rule will always be applied.

\section{Conclusion}

It is hoped that the policies outlined in the first part of this paper are correctly reflected in the rules of the Restatement Second. Fairly precise rules have in general been stated in the case of status, corporations, and property, since, on the basis of present knowledge, it is deemed possible to identify and to give effect to the most important policies in these areas. Present experience, on the other hand, with respect to contracts and torts does not permit the formulation of definite rules with any reasonable assurance that these rules would give appropriate effect to what are here the most significant policies. Hence the more general and more flexible formulation of "state of most significant relationship" has been resorted to. Presumably more definite and precise rules can be stated after more experience has accumulated. That will be the task of future Restatements.

\footnotetext{
"2 See generally Mofpatt Hancock, ToRTs in the Conplict of Laws (1942).

- SSee, e.g., Grant v. McAuliffe, 4I Cal.2d 859, 264 P.2d 944 (1953); Schmidt v. Driscoll Hotels, 249 Minn. 376, 82 N.W.2d 365 (1957); Babcock v. Jackson, I2 N.Y.2d 473, rgx N.E.2d 279 (I963); Kilberg v. Northeast Airlines, 9 N.Y.2d 34, I72 N.E.2d 526 (196I).

a Restatement (Second), Conflict of Laws $\$ 379$ (Tent. Draft No. 8, 1963).

"Id. I 379a-379k.
} 